Jurnal Pengurusan 61(2021) $57-68$

https://doi.org/10.17576/pengurusan-2021-61-05

\title{
Kesan Tanggapan Politik Terhadap Tingkah Laku Menyembunyikan Pengetahuan: Konflik sebagai Pengantara
}

\author{
(The Effect of Perceived Politics on Knowledge Hiding Behaviour: Conflict as a Mediator) \\ Norulhuda Tajuddin \\ (UKM-Graduate School of Business, Universiti Kebangsaan Malaysia) \\ (Fakulti Pengurusan Perniagaan, Universiti Teknologi MARA) \\ Rasidah Arshad \\ (Fakulti Ekonomi dan Pengurusan, Universiti Kebangsaan Malaysia)
}

ABSTRAK

Tingkah laku menyembunyikan pengetahuan didapati memberi kesan negatif bukan sahaja kepada pekerja tetapi juga kepada organisasi secara keseluruhan. Sorotan literatur menunjukkan tingkah laku menyembunyikan pengetahuan di tempat kerja dipengaruhi oleh faktor berkaitan diri pekerja dan faktor situasi yang berkaitan dengan organisasi. Kajian ini dijalankan untuk menguji hubungan antara tanggapan politik dengan tingkah laku menyembunyikan pengetahuan dalam kalangan pekerja yang bekerja dalam pasukan. Secara khususnya, kajian ini menghipotesiskan wujudnya kesan langsung tanggapan politik terhadap tingkah laku menyembunyikan pengetahuan, serta kesan tidak langsung menerusi konflik hubungan sebagai pengantara. Model Persamaan Berstruktur digunakan untuk menguji hipotesis berdasarkan data daripada 339 orang ahli akademik yang menjalankan penyelidikan secara berpasukan. Dapatan kajian ini menunjukkan hubungan langsung dan tidak langsung yang signifikan antara tanggapan politik dengan tingkah laku menyembunyikan pengetahuan, serta hubungan tidak langsung menerusi konflik hubungan sebagai pengantara. Secara teorinya, kajian ini menyumbang kepada literatur menerusi penggunaan teori pemuliharaan sumber dalam menerangkan tingkah laku menyembunyikan pengetahuan di tempat kerja.

Kata Kunci: Tingkah laku menyembunyikan pengetahuan; tanggapan politik; konflik hubungan, pasukan kerja.

ABSTRACT

Knowledge hiding behavior among employees was found to not only harm employees but also the organization as a whole. A review of literature showed that knowledge hiding behavior is influenced by individual and situational factors related to organization. The present study examines the relationship between perceived politics and knowledge hiding behavior among employees working team. Specifically, this study hypothesized both direct relationships between perceived politics and knowledge hiding behavior, and indirect relationship between the two variables via relationhip conflict. Structural Equation Modeling was employed to analyze the survey data collected from 339 academicians who are working in research projects in team. The results showed significant direct effect of perceived politics on knowledge hiding behavior, and indirect effect through relationship conflict as the mediator. Theoretically, this study contributes to the existing literature by expanding the utility of the conservation of resource theory in explaining knowledge hiding behavior at the workplace.

Keywords: Knowledge hiding; perceived politics; relational conflict; work team.

\section{PENGENALAN}

Pengurusan pengetahuan yang berkesan merupakan faktor penting dalam menentukan prestasi dan kelangsungan sesebuah organisasi. Justeru, organisasi sanggup memperuntukkan pelaburan yang tinggi dalam memastikan berlakunya pemindahan dan perkongsian pengetahuan dalam kalangan pekerja. Syarikatsyarikat perniagaan di negara maju seperti di Amerika Syarikat dan United Kingdom misalnya dilaporkan telah membelanjakan sejumlah wang yang besar dalam menyediakan prasarana dan peralatan; membangunkan sistem dan pangkalan data; serta memberikan latihan untuk pekerja sebagai usaha menggalakkan perkongsian pengetahuan (Panopto 2018; Mitratech Holdings Inc 2016). Usaha ini juga dapat dilihat di Malaysia, di mana Kementerian Pengajian Tinggi, contohnya, telah memperuntukkan wang sebanyak RM250 juta pada tahun 2020 untuk menjana ilmu pengetahuan yang seterusnya dapat dikongsi bersama, menerusi aktiviti penyelidikan dan pembangunan (Sinar Harian 2020). Walaubagaimanapun, pelaburan ini tidak akan mendapat pulangan seperti yang dijangkakan sekiranya pengetahuan gagal dikongsi bersama. Sebagai contoh, tindakan ahli pasukan projek penyelidikan menyembunyikan pengetahuan yang dimiliki daripada rakan sepasukan akan memberi impak negatif kepada hasil penyelidikan yang dijalankan. Ini seterusnya akan 
menjejaskan matlamat kerajaan dalam menjana ilmu pengetahuan berkualiti sebagai pulangan daripada geran penyelidikan yang diberikan kepada para penyelidik.

Tingkah laku menyembunyikan pengetahuan dirujuk sebagai keengganan seseorang untuk memberikan pengetahuan atau maklumat yang diminta oleh pihak lain (Connelly et al. 2012), dan dianggap sebagai satu bentuk tingkah laku yang negatif di tempat kerja. Ia telah mula diberikan perhatian oleh para penyelidik dan pengamal industri disebabkan oleh kesan buruk yang terhasil daripada tingkah laku ini, sama ada terhadap pekerja mahupun organisasi. Pada peringkat organisasi, kajian lepas melaporkan bahawa tingkah laku menyembunyikan pengetahuan boleh meningkatkan niat pekerja untuk berhenti kerja dan seterusnya menjejaskan prestasi kerja secara keseluruhannya (Serenko \& Bontis 2016; Bogilović et al. 2017). Sementara itu, kajian lepas juga mendapati tingkah laku menyembunyikan pengetahuan memberikan kesan negatif pada peringkat individu; antaranya, mengurangkan tingkah laku berinovasi (Černe et al. 2017) dan kreativiti pekerja (Malik et al. 2019; Rhee \& Choi 2017), menjejaskan hubungan sesama rakan sekerja (Cerne et al. 2015; Connelly et al. 2012), serta menimbulkan perasaan bersalah dan malu dalam kalangan pekerja (Burmeister et al. 2019).

Dalam usaha membendung kesan buruk tersebut, para penyelidik telah menyiasat faktor-faktor yang mendorong tingkah laku menyembunyikan pengetahuan dalam kalangan pekerja. Antara peramal kepada tingkah laku menyembunyikan pengetahuan yang telah dikenalpasti dalam kajian lepas termasuklah faktor perbezaan individu seperti personaliti (Iqbal et al. 2020) dan orientasi individu (Rhee \& Choi 2017). Terdapat juga faktor-faktor organisasi yang mempengaruhi tingkah laku ini, antaranya: i) gaya kepimpinan seperti kepimpinan beretika (Men et al. 2018) dan pertukaran pemimpinpengikut (Zhao et al. 2019); ii) iklim persekitaran yang tidak kondusif (Han et al. 2020); iii) hubungan antara perorangan seperti ketidakpercayaan (Conelly et al. 2012) dan ketidakadilan (Arendt et al. 2021); dan iv) layanan buruk seperti tingkah laku kurang sopan (Arshad \& Ismail 2018) dan gosip (Yao et al. 2020). Walau bagaimanapun, berdasarkan kepada penelitian terhadap literatur, kajian mengenai faktor peramal yang berkaitan dengan kuasa dan pengaruh dalam organisasi masih lagi terhad. Kuasa dan pengaruh merupakan antara faktor penting yang sering dikaji dalam memahami tingkah laku pekerja dalam organisasi (Rosen et al. 2016; Hochwarter 2020). Sehingga kini hanya satu sahaja kajian yang mengkaji hubungan antara tanggapan politik organisasi dan tingkah laku menyembunyikan pengetahuan (Malik et al. 2019).

Tanggapan politik merupakan pemboleh ubah yang relevan dalam memahami tingkah laku menyembunyikan pengetahuan dalam kalangan pekerja. Semasa menjalankan tugas, para pekerja yang bekerja dalam sesebuah pasukan kerja perlu bertukartukar idea dan berkongsi pengetahuan untuk mencapai matlamat pasukan. Sinergi dapat dicapai apabila ahli pasukan bersama-sama menggembleng usaha ke arah pencapaian matlamat (Van Knippenberg et al. 2020). Walau bagaimanapun, tingkah laku menyembunyikan pengetahuan akan menghalang pencapaian matlamat kerana maklumat atau pengetahuan yang sepatutnya dikongsi bersama rakan sepasukan telah disembunyikan oleh ahli pasukan. Satu daripada punca berlakunya tingkah laku tersebut adalah manipulasi kuasa dan pengaruh (Malik et al. 2019). Kuasa dan pengaruh memainkan peranan penting dalam kehidupan organisasi kerana proses pembuatan keputusan dan keputusan yang dicapai biasanya dikawal oleh mereka yang berkuasa atau berpengaruh. Justeru kajian ini menyiasat hubungan langsung di antara tanggapan politik dan tingkah laku menyembunyikan pengetahuan dalam kalangan pekerja yang bekerja dalam pasukan.

Selain daripada kesan langsung, kesan tidak langsung tanggapan politik terhadap tingkah laku menyembunyikan pengetahuan juga penting untuk difahami. Sorotan literatur menunjukkan kajian mengenai mekanisma atau pengantara yang menghubungkan keduadua pemboleh ubah tersebut secara tidak langsung masih lagi terhad (cth. Baloch et al. 2017; Bedi \& Schat 2013). Secara amalannya, apabila bekerja secara berpasukan, pekerja diharapkan dapat berhubung dan berkomunikasi dengan baik serta harmoni antara satu sama lain untuk memastikan kerja-kerja dapat dijalankan dengan sempurna. Hubungan yang baik juga adalah penting untuk memastikan perkongsian pengetahuan berlaku (Abrams et al. 2003). Namun begitu, penglibatan dalam politik yang tinggi dalam pasukan kerja boleh membawa kepada salah faham atau konflik yang melibatkan emosi, dan seterusnya akan mempengaruhi pekerja dalam pasukan itu untuk menyembunyikan pengetahuan. Dalam hal ini konflik berperanan sebagai pengantara bagi hubungan tidak langsung antara tanggapan politik dengan tingkah laku menyembunyikan pengetahuan. Secara empirikal, sorotan literatur juga menunjukkan kajian mengenai mekanisma yang menghubungkan kedua-dua pemboleh ubah tersebut masih lagi terhad (Connelly et al. 2012).

Justeru, berdasarkan kepada hujah-hujah di atas, kajian ini dijalankan untuk menyiasat hubungan langsung antara tanggapan politik dengan tingkah laku menyembunyikan pengetahuan dalam kalangan pekerja dalam pasukan; dan, hubungan tidak langsung antara tanggapan politik dan tingkah laku menyembunyikan pengetahuan menerusi konflik hubungan yang bertindak sebagai pemboleh ubah pengantara.

\section{ULASAN LITERATUR DAN PEMBANGUNAN HIPOTESIS}

\section{TINGKAH LAKU MENYEMBUNYIKAN PENGETAHUAN}

Tingkah laku menyembunyikan pengetahuan boleh didefinisikan sebagai tingkah laku yang dilakukan 
secara sengaja untuk tidak mendedahkan maklumat apabila ianya diminta oleh pihak lain (Connelly et al. 2012). Tingkah laku menyembunyikan pengetahuan adalah berbeza daripada tingkah laku tidak berkongsi pengetahuan (not sharing). Dari segi definisi, tingkah laku berkongsi pengetahuan merujuk kepada aktiviti yang berlaku secara sukarela tanpa diminta oleh orang lain (Nonaka 1994; Wang \& Noe 2010); tidak berkongsi pengetahuan mempunyai maksud yang berlawanan dengan berkongsi pengetahuan. Sebaliknya, tingkah laku menyembunyikan pengetahuan terjadi apabila seseorang dengan sengaja tidak mahu berkongsi maklumat yang secara khususnya diminta oleh orang lain. Dengan kata lain, konstruk ini didasari oleh elemen 'niat' serta 'keengganan' memberikan maklumat yang 'diminta' oleh orang lain (Connelly et al. 2012). Elemen-elemen ini tidak diberi penekanan dalam konstruk-konstruk lain yang berkaitan dengan pengurusan maklumat.

Tingkah laku menyembunyikan pengetahuan telah mula diberikan perhatian oleh para penyelidik bidang pengurusan pengetahuan setelah sekian lama tumpuan diberikan kepada tingkah laku pengetahuan yang positif iaitu berkongsi pengetahuan (cth. Kwahk \& Park 2016; Yun \& Lee 2017). Sejak konstruk menyembunyikan pengetahuan ini diperkenalkan oleh Connelly et al. (2012), semakin banyak penyelidikan yang dilakukan bagi memahami anteseden dan kesan tingkah laku tersebut kepada pekerja secara individu dan organisasi secara keseluruhan. Secara umumnya, antara isu-isu relevan yang dikenalpasti sebagai punca yang menyebabkan sebahagian individu cenderung untuk tidak berkongsi pengetahuan mereka, atau dalam kes yang lebih ekstrem terlibat dengan tingkah laku menyembunyikan pengetahuan adalah hak pemilikan (Ghani et al 2020), sistem ganjaran (Bartol \& Srivastava 2002), menumpang usaha orang lain (Cabrera \& Cabrera 2002) dan pandangan bahawa 'ilmu adalah kuasa' (Filstad et al. 2018)

Dari segi kesan tingkah laku menyembunyikan pengetahuan pula, kajian mendapati tingkah laku tersebut memberi kesan negatif sama ada kepada pihak yang meminta pengetahuan tersebut (pengetahuan disembunyikan kepada mereka) mahupun kepada penyembunyi pengetahuan itu sendiri. Bagi pihak yang meminta pengetahuan, kajian mendapati kesan tingkah laku ini akan menjejaskan kreativiti (Rhee \& Choi 2017), tingkah laku berinovasi (Černe et al. 2017), dan seterusnya prestasi kerja mereka (Serenko \& Bontis 2016; Malik et al. 2019). Sementara itu, pihak yang menyembunyikan pengetahuan juga turut mengalami tahap kreativiti yang rendah dalam kerja mereka apabila menerima timbal balas yang sama setelah menyembunyikan pengetahuan dari orang lain (Cerne et al. 2015). Penyembunyi pengetahuan juga cenderung untuk mengalami kemerosotan untuk berkembang maju (Zhou et al. 2019) disebabkan oleh tanggapan negatif mereka terhadap keselamatan dan jaminan persekitaran kerja yang menyebabkan mereka bertindak menyembunyikan pengetahuan.
Kajian yang dijalankan pada tahap pasukan kerja pula melaporkan kesan negatif tingkah laku menyembunyikan pengetahuan terhadap kreativiti dan prestasi pasukan kerja (Bogilović et al. 2017; Fong et al. 2018). Zhang dan Min (2019) mendapati ahli pasukan yang menyembunyikan pengetahuan mereka daripada rakan sepasukan menyebabkan proses pemindahan pengetahuan menjadi terbantut dan seterusnya menjejaskan prestasi projek mereka. Manakala Bogilović et al. (2017) pula melaporkan tindakan menyembunyikan pengetahuan sesama ahli pasukan mengakibatkan ahliahli tidak berupaya menghasilkan kreativiti dalam idea dan kerja mereka.

Dalam usaha memahami tingkah laku menyembunyikan pengetahuan, kajian lepas telah mengenalpasti dua kategori peramal kepada tingkah laku menyembunyikan pengetahuan: faktor perbezaan individu dan faktor situasi atau persekitaran organisasi. Antara perbezaan individu yang dilaporkan mempengaruhi kecenderungan seseorang untuk menyembunyikan pengetahuan adalah personaliti seperti Big Five Personality traits (Iqbal et al. 2020), Machiavellian (Pan et al. 2016), personaliti berdaya saing (Hernaus et al. 2018), dan orientasi matlamat (Zhao \& Xia 2019). Manakala bagi faktor situasi pula, hubungan antara perorangan (Semerci 2018; Babic et al. 2019), iklim organisasi (Han et al. 2020), budaya organisasi (Serenko \& Bontis 2016), gaya kepimpinan (Babic et al. 2019; Ghani et al. 2020), kelakuan tidak sopan (Arshad \& Ismail 2018; Yao et al. 2020), sifat pengetahuan dan tugasan itu sendiri (Peng 2013; Connelly et al. 2012) didapati meramal tingkah laku menyembunyikan pengetahuan.

Satu lagi faktor situasi yang diberi perhatian dalam memahami tinglah laku berkaitan pengetahuan dalam kalangan pekerja adalah tanggapan politik organisasi (Malik et al. 2019). Secara umumnya, dalam konteks organisasi, atau pasukan secara khususnya, para pekerja mempunyai kecenderungan untuk melibatkan diri dalam aktiviti politik untuk memastikan mereka dapat mencapai kepentingan kendiri yang akan menguntungkan mereka. Walau bagaimanapun, tingkah laku tersebut akan memberi kesan kepada rakan sekerja dalam organisasi atau pasukan (Rosen et al. 2016; Hochwarter 2020). Pekerja lain melihat aktiviti atau tingkah laku politik tersebut sebagai ancaman kepada mereka; dan seterusnya mengakibatkan pekerja itu mengambil tindakan bagi menjaga kedudukan mereka daripada ancaman tersebut (Hobfoll 1989). Dalam konteks di mana pengetahuan dianggap sebagai sumber penting, pekerja yang bekerja dalam pasukan akan bertindak menyembunyikan pengetahuan yang mereka miliki apabila diminta oleh rakan sepasukan. Kajian longitudinal yang dijalankan oleh Malik et al. (2019) mendapati hubungan yang positif dan signifikan antara tanggapan politik organisasi dengan tingkah laku menyembunyikan pengetahuan. Namun, setakat ini kajian antara kedua-dua pemboleh ubah dan mekanisma yang mendasari hubungan ini juga masih lagi terhad. 


\section{TANGGAPAN POLITIK DALAM PASUKAN}

Politik organisasi merupakan konsep yang penting dan dan telah dikaji sejak lama dahulu dalam bidang psikologi organisasi (cth. Ferris et al. 1996; Bai et al. 2015; Kumar \& Ghadially 1989; Vigoda-Gadot 2019). Politik organisasi biasanya diukur menerusi tanggapan pekerja terhadap aktiviti politik dalam sesebuah organisasi. Dalam kajian ini, tanggapan politik didefinisikan dalam konteks pasukan sebagai penilaian seseorang terhadap aktivitiaktiviti manipulasi kuasa dan pengaruh dalam pasukan untuk kepentingan diri sendiri dengan mengakibatkan kerugian kepada rakan sepasukan (Ferris et al. 1996; Hochwarter et al. 2003). Secara khususnya, apabila bekerja dalam pasukan, wujud keadaan di mana ahliahli menggunakan taktik politik seperti mempengaruhi keputusan-keputusan penting dalam pasukan bagi memenuhi kepentingan kendiri (Rosen et al. 2016; Witt et al. 2001; Bai et al. 2015).

Tingkah laku politik dianggap sebagai sesuatu kelakuan tidak produktif dan telah dibuktikan membawa pelbagai kesan negatif kepada pekerja dan organisasi secara keseluruhannya. Kajian-kajian lepas mendapati aktiviti politik dalam organisasi akan menyebabkan pekerja cenderung untuk berdiam diri (Sun \& Xia 2018), menjejaskan kreativiti pekerja (Malik et al. 2019) serta mendorong pekerja untuk terlibat dalam tingkah laku negatif (Wiltshire et al. 2013; Zettler \& Hilbig 2010). Meisler et al. (2019), misalnya, mendapati politik yang tinggi mempengaruhi pekerja untuk terlibat dalam tingkah laku tidak produktif yang disasarkan sama ada kepada organisasi mahupun kepada individu. Antara tindakan tersebut termasuklah sabotaj, mencuri barang pejabat, menyebarkan khabar palsu dan ponteng kerja (Bennett \& Robinson, 2000; Penney \& Spector 2008), dan dilakukan oleh pekerja sebagai balasan ketidakpuasan hati terhadap aktiviti politik dalam organisasi mereka. Sehubungan itu, tanggapan politik dalam kalangan pekerja yang bekerja dalam pasukan juga berkemungkinan besar akan memberi impak negatif kepada tingkah laku pekerja dan prestasi pasukan secara keseluruhan. Ini adalah disebabkan aktiviti politik tidak hanya menggugat kepentingan rakan sekerja yang lain tetapi juga matlamat pasukan yang mereka sertai (Bai et al. 2015; Rosen et al. 2016).

\section{KONFLIK HUBUNGAN}

Selain daripada hubungan langsung antara tanggapan politik dengan tingkah laku menyembunyikan pengetahuan, kajian ini juga menyiasat peranan konflik hubungan sebagai mekanisme yang menghubungkan kedua-dua konstruk tersebut dengan secara tidak langsung. Konflik hubungan merupakan satu dari tiga konsep asas berkaitan konflik iaitu, konflik tugas, konflik proses dan konflik hubungan (Jehn 1997). Konflik tugas dan konflik proses adalah konflik yang berkaitan dengan kerja dan tugasan, manakala konflik hubungan pula berkaitan rapat dengan hubungan antara perorangan dalam kalangan rakan sekerja. Konflik hubungan merujuk kepada perselisihan antara dua pihak yang melibatkan nilai, fahaman dan kepercayaan individu dan melibatkan emosi yang boleh mencetuskan rasa tidak selesa, tekanan dan ketidakfahaman antara rakan sekerja (de Wit et al. 2012; Bai et al. 2015).

Antara punca konflik hubungan yang telah dikenalpasti oleh kajian lepas termasuklah kebergantungan tugasan (Wall \& Callister 1995), konflik kerja (De Dreu \& Weingart 2003) dan kepelbagaian latar belakang individu seperti perbezaan umur (Mohammed \& Angell 2004). Manakala, kesan konflik tersebut pula adalah tindakan merendah-rendahkan orang lain (Yu \& Zellmer-Bruhn 2017), memberi layanan buruk (Sulea et al. 2012), mengurangkan kreativiti (Jung \& Lee 2015) serta prestasi kerja (Manata 2016), dan tingkah laku menyembunyikan pengetahuan (Semerci 2018).

\section{TANGGAPAN POLITIK DAN TINGKAH LAKU MENYEMBUNYIKAN PENGETAHUAN}

Hubungan antara tanggapan politik dan tingkah laku menyembunyikan pengetahuan boleh dijelaskan dengan menggunakan teori pemuliharaan sumber (Hobfoll 1989). Menurut teori tersebut, para pekerja bergantung kepada sumber untuk melaksanakan pekerjaan mereka dan mereka sentiasa berdepan dengan situasi di mana berlakunya pertambahan atau pengurangan sumber yang berlaku sama ada dalam bentuk ancaman atau kehilangan sebenar (Hobfoll 1989). Ancaman kehilangan sumber mungkin boleh berlaku dalam bentuk perebutan sumber yang terhad seperti agihan belanjawan, kenaikan pangkat atau kekosongan jawatan.

Selain dari teori pemuliharaan sumber, hubungan secara langsung antara kedua-dua pemboleh ubah juga boleh diterangkan menggunakan teori pertukaran sosial (Blau 1964) bersama norma timbal balas (Gouldner 1960). Teori pertukaran sosial menerangkan bahawa para pekerja yang bekerja dalam pasukan saling memerlukan antara satu sama lain dan mengharapkan balasan yang setimpal setelah berkongsi pelbagai sumber seperti maklumat, kepakaran dan persahabatan untuk melaksanakan tugas-tugas bersama dan seterusnya mencapai matlamat pasukan. Oleh itu, suasana politik yang tinggi dalam kalangan ahli pasukan ini akan menyebabkan terjadinya ketidakpastian dan kekaburan yang menjejaskan hubungan pertukaran antara mereka. Tingkah laku politik seperti mempengaruhi keputusan dalam pasukan agar selari dengan matlamat individu dianggap sebagai pengkhianatan kepada hubungan pertukaran (cth: persahabatan, pengetahuan) antara mereka. Justeru, sebagai timbal balas layanan buruk itu, pekerja cenderung untuk bertindak menyembunyikan pengetahuan yang diminta oleh rakan sepasukannya sendiri.

Dalam konteks pekerja yang bekerja secara berpasukan, penglibatan pekerja yang tinggi dalam 
tingkah laku politik juga boleh dilihat sebagai ancaman kepada sumber yang dimiliki oleh pasukan. Mereka melihat penglibatan rakan sepasukan dalam tingkah laku politik sebagai ancaman kepada sumber yang ada dalam pasukan. Sebagai cara untuk memulihara sumber yang terancam, terutamanya berkaitan dengan sumber pengetahuan, pekerja akan bertindak menyembunyikan maklumat seperti yang diminta oleh rakan sepasukan (Hobfoll 1989).

Secara empirikal, hubungan antara tanggapan politik dan tingkah laku menyembunyikan pengetahuan ini telah disokong oleh kajian lepas (cth., Malik et al. 2019; Baloch et al. 2017; Cohen \& Diamant 2017). Malik et al. (2019), misalnya, telah menjalankan kajian longitudinal mengkaji hubungan tanggapan politik organisasi dan tingkah laku menyembunyikan pengetahuan di kalangan ahli akademik di Pakistan. Konsisten dengan teori permintaan-sumber kerja (Bakker \& Demerouti 2007), politik dalam organisasi didapati meningkatkan tuntutan kerja dan seterusnya akan menjejaskan sumber yang diperlukan dalam melaksanakan kerja. Situasi ini seterusnya akan mendorong pekerja untuk menyembunyikan maklumat yang diminta oleh rakan sekerja. Berdasarkan penjelasan teori dan empirikal di atas, kajian ini mencadangkan hipotesis yang berikut:

$\mathrm{H}_{1} \quad$ Tanggapan politik dalam pasukan berhubung secara positif dengan tingkah laku menyembunyikan pengetahuan

\section{TANGGAPAN POLITIK DAN KONFLIK HUBUNGAN}

Teori pemuliharaan sumber (Hobfoll 1989) boleh digunakan untuk menerangkan hubungan tanggapan politik dengan konflik hubungan dalam kalangan pekerja yang bekerja dalam pasukan. Berdasarkan kepada premis asas dalam teori ini mengenai kebergantungan kepada sumber, pekerja diandaikan sebagai peka terhadap sebarang ancaman terhadap sumber yang mereka miliki. Aktiviti politik yang tinggi akan meningkatkan kekaburan dan seterusnya memberikan ancaman kepada sumber yang ada dalam pasukan kerja. Sebagai contoh, pekerja yang mengambil kredit individu terhadap kerja pasukan sebagai cara untuk memenangi hati ketua akan menyebabkan pekerja lain melihat sumber-sumber mereka sebagai terancam. Tindakan rakan sepasukan tersebut dilihat sebagai mementingkan diri sendiri dan membelakangkan kepentingan pasukan. Situasi ini akan menyebabkan pekerja mengambil pendekatan mengelakkan diri dari berhubungan, berinteraki atau berkomunikasi dengan rakan sekerja tersebut. Seterusnya, keadaan ini akan melarat sehingga mencetuskan konflik hubungan dalam kalangan pekerja.

Secara empirikal, hubungan antara tanggapan politik dan konflik hubungan disokong oleh kajian Bai et al.
(2015) yang mendapati aktiviti politik yang tinggi dalam kalangan ahli menyebabkan matlamat pasukan kerja terjejas dan seterusnya mengakibatkan pertelingkahan berasaskan emosi antara pekerja. Berdasarkan kepada hujah-hujah yang diberikan, kajian ini mencadangkan hipotesis berikut:

$\mathrm{H}_{2}$ Tanggapan politik dalam pasukan berhubung secara positif dengan konflik hubungan

\section{KONFLIK HUBUNGAN DAN TINGKAH LAKU MENYEMBUNYIKAN PENGETAHUAN}

Perselisihan faham atau konflik yang melibatkan hubungan emosi dengan rakan sekerja yang berlaku kerana perbezaan nilai, fahaman atau sikap akan menjejaskan hubungan mesra antara pekerja (De Dreu \& Weingart 2003; Jehn 1997). Para pekerja yang terlibat dengan konflik akan cuba mengelak daripada berhubungan atau berinteraksi dengan satu sama lain. Keadaan ini akan berlanjutan hingga menjejaskan hubungan dalam melaksanakan tugasan terutamanya apabila mereka bekerja secara berpasukan. Konflik yang dilihat sebagai ancaman kepada sumber akan menyebabkan pekerja yang mempunyai maklumat atau kemahiran tertentu bertindak menyembunyikan maklumat tersebut apabila diminta oleh rakan sekerja sebagai cara untuk memulihara sumber yang dimiliki (Hobfoll 1989). Semakin tinggi tahap konflik hubungan dalam kalangan pekerja maka, kecenderungan untuk pekerja terlibat dengan tingkah laku menyembunyikan pengetahuan juga tinggi.

Selain itu, hubungan antara konflik hubungan dan tingkah laku menyembunyikan pengetahuan juga telah disokong secara empirikal oleh kajian-kajian lepas. Sebagai contoh, Yu dan Zellmer-Bruhn (2017), mendapati pekerja yang terlibat dalam konflik hubungan cenderung untuk merendahkan rakan sekerja mereka sendiri. Sementara itu, kajian Sulea et al., (2012) melaporkan bahawa konflik hubungan di tempat kerja akan menyebabkan pekerja menimbal balas layanan buruk itu dengan aktiviti tidak produktif seperti datang lambat dan melengah-lengahkan kerja. Manakala Semerci (2018) pula mendapati terdapat hubungan langsung antara konflik hubungan dan tingkah laku menyembunyikan pengetahuan. Beliau menggunakan teori pertukaran sosial (Blau 1964) dalam menerangkan hubungan tersebut; apabila pekerja merasakan hubungan sesama mereka tidak lagi harmoni mengakibatkan keadaan itu perlu dibalas seperti keengganan berkerjasama dan seterusnya menyembunyikan pengetahuan (Gouldner 1960). Berdasarkan kepada hujah teoretikal dan empirikal yang dibincangkan di atas, maka kajian ini menghipotesiskan:

$\mathrm{H}_{3}$ Konflik hubungan berhubung secara positif dengan tingkah laku menyembunyikan pengetahuan. 
KONFLIK HUBUNGAN SEBAGAI PENGANTARA DALAM HUBUNGAN ANTARA TANGGAPAN POLITIK DALAM PASUKAN DENGAN TINGKAH LAKU MENYEMBUNYIKAN PENGETAHUAN

Dalam kajian ini, konflik hubungan dicadangkan bertindak sebagai pemboleh ubah pengantara dalam hubungan antara tanggapan politik dan tingkah laku menyembunyikan pengetahuan. Teori pemuliharaan sumber (Hobfoll 1989) digunakan bagi menerangkan hubungan ini bersesuaian dengan situasi pekerja yang sentiasa berusaha untuk mendapatkan dan memulihara sumber-sumber yang diperlukan untuk menjalankan tugas-tugas seharian mereka. Apabila para pekerja merasakan wujudnya ancaman kehilangan sumber, mereka akan cuba untuk mempertahankan sumbersumber yang mereka miliki bagi memastikan mereka boleh menghadapi suasana yang menyukarkan itu.

Dalam konteks pekerja yang bekerja dalam pasukan, penglibatan dalam politik berlaku apabila ahli melakukan sesuatu tindakan yang bertujuan untuk mencapai kepentingan kendiri berbanding pencapaian pasukan. Antaranya termasuklah mengambil kredit hasil kerja berpasukan sebagai hasil kerja sendiri dan mempengaruhi keputusan pasukan agar selari dengan matlamat individu (Bai et al. 2015; Witt et al. 2001). Tingkah laku politik yang ditunjukkan oleh pekerja tersebut dilihat sebagai sebagai ancaman kepada sumber-sumber yang dimiliki oleh pasukan atau oleh pekerja yang lain (Hobfoll 1989), yang akan mencetuskan kekeliruan dan kekaburan dalam pasukan dan seterusnya menggugat emosi dan hubungan yang baik antara rakan sekerja. Keadaan ini yang dikenali sebagai konflik hubungan akan berlarutan dan menjadikan pekerja cuba mengelak daripada berinteraksi atau bekerjasama dengan rakan sepasukan. Seterusnya, konflik hubungan ini akan menyebabkan para pekerja enggan berkongsi pengetahuan mereka dan bertindak untuk menyembunyikan pengetahuan apabila diminta oleh rakan sekerja atau sepasukan. Tindakan ini dianggap sebagai usaha mereka untuk memulihara sumber-sumber yang mereka miliki. Dalam situasi ini, konflik hubungan dilihat sebagai mekanisme pengantara yang menghubungkan tanggapan politik dalam pasukan dengan tingkah laku menyembunyikan pengetahuan.

Secara empirikal, hubungan antara ketiga-tiga pemboleh ubah tersebut disokong oleh dapatan daripada kajian lepas. Bai et al. (2015), misalnya, menyiasat peranan konflik hubungan sebagai pengantara antara tanggapan politik dengan tiga jenis prestasi kerja: i) peranan dalaman ii) kreativiti dan iii) tingkah laku kewargaan organisasi. Hasil dapatan kajian mereka mendapati konflik hubungan bertindak sebagai pengantara yang signifikan dalam hubungan antara tanggapan politik dengan ketiga-tiga jenis prestasi kerja tersebut.

Secara kesimpulan, berdasarkan bukti-bukti teoretikal dan emprikal mengenai peranan konflik hubungan sebagai pengantara dalam hubungan antara tanggapan politik dan tingkah laku menyembunyikan pengetahuan, kami mencadangkan hipotesis berikut:

$\mathrm{H}_{4}$ Konflik hubungan bertindak sebagai pengantara dalam hubungan antara tanggapan politik dalam pasukan dengan tingkah laku menyembunyikan pengetahuan

\section{KAEDAH KAJIAN}

\section{SAMPEL KAJIAN DAN KAEDAH PENGUMPULAN DATA}

Kajian ini menggunakan data daripada 339 responden yang merupakan individu yang bekerja dalam pasukan. Responden merupakan ahli akademik di beberapa buah universiti di Malaysia yang bekerja sama dalam pasukan penyelidikan. Ahli akademik dipilih kerana, selain daripada pengajaran, penyelidikan juga merupakan salah satu penunjuk prestasi utama yang perlu dicapai. Oleh itu, melibatkan diri dalam projek-projek penyelidikan yang biasanya dilakukan secara berpasukan adalah amalan ahli akademik. Persampelan bertujuan yang digunakan dalam kajian ini mensyaratkan responden mesti sedang menganggotai pasukan penyelidikan yang memiliki geran penyelidikan (cth: TRGS, FRGS, GUP dil) dengan tempoh kajian dua tahun atau lebih. Proses pengumpulan data dijalankan secara keratan rentas dengan menggunakan kaedah tinjauan menggunakan soal selidik yang diedarkan secara bersemuka atau menerusi e-mail. Setiap responden diberikan satu set soal selidik yang mengandungi surat yang menerangkan tujuan kajian, kerahsiaan dan kesukarelaan penglibatan, berserta soal selidik laporan-kendiri. Daripada 700 soal selidik yang diedarkan, 450 telah dikembalikan, dan 339 sesuai untuk digunakan dalam kajian ini.

Analisis terhadap maklumat latar belakang menunjukkan majoriti responden terdiri daripada wanita iaitu sebanyak 52.5 peratus berbanding dengan responden lelaki sebanyak 47.5 peratus. Majoriti responden (90.1\%) adalah melayu; manakala dari segi umur pula, seramai 176 orang $(53 \%)$ berumur sekitar 36 hingga 45 tahun, 20.6 peratus berumur dari 46 hingga 55 tahun, 20.4 peratus berumur 29 hingga 35 tahun dan selebihnya berumur 56 tahun ke atas. Majoriti daripada responden memiliki sijil ijazah kedoktoran $(75.8 \%)$, dan selebihnya memiliki ijazah sarjana $(23.3 \%)$ dan sarjana muda (0.9\%). Dari segi bidang kepakaran pula, 49.5 peratus responden adalah daripada bidang sains, 48.5 peratus adalah sains sosial, dan selebihnya adalah daripada jurusan seni.

\section{PENGUKURAN KONSTRUK}

Tingkah laku menyembunyikan pengetahuan diukur menggunakan pengukuran yang dibangunkan oleh Connelly et al. (2012). Bagi memastikan soal selidik 
dijawab berdasarkan konteks kerja dalam pasukan, penyelidik menyediakan di awal soal selidik dengan ayat "Dalam situasi di mana rakan sepasukan meminta sesuatu maklumat, dan anda menolaknya...", dan seterusnya menjawab persoalan yang ditimbulkan. Contoh penyataan yang diberikan adalah "saya berpurapura tidak tahu mengenai maklumat tersebut".

Tanggapan politik diukur menggunakan instrumen yang dibangunkan oleh Hochwarter et al. (2003). Contohnya pernyataan berkaitan tanggapan politik adalah: "ahli pasukan saya melakukan yang terbaik untuk diri mereka sendiri berbanding kebaikan untuk pasukan”.

Konflik hubungan pula diadaptasi daripada instrumen yang dibangunkan oleh Jehn (1995). Contoh pernyataan dalam pengukuran konstruk ini seperti "terdapat banyak perpecahan di kalangan ahli dalam pasukan ini"

Dalam soal selidik ini, responden diminta untuk menyatakan tahap persetujuan mereka terhadap penyataan yang diberikan dengan menggunakan skala Likert yang bermula dari 1 (sangat tidak setuju) hingga 5 (sangat setuju).

\section{DAPATAN KAJIAN}

Permodelan Persamaan Berstruktur (Structural Equation Modeling) menggunakan perisian AMOS, dengan prosedur dua-langkah (Anderson \& Gerbing 1988) telah dijalankan untuk menguji hipotesis kajian. Dalam langkah pertama, model pengukuran penuh dengan petunjuk nyata (manifest indicators) diuji dari segi kesahan dan kebolehpercayaan dengan menggunakan Analisis Faktor Pengesahan (Confirmatory Factor Analysis). Manakala, dalam langkah kedua pula, pengujian dilakukan terhadap model berstruktur penuh untuk menentukan sama ada hipotesis diterima atau ditolak. Beberapa indeks telah dipilih untuk menilai sama ada model diterima sebagai mempunyai padanan yang baik atau pun tidak: ChiSquare, Comparative Fit Index (CFI), Tucker-Lewis Index (TLI), Standardised Root Mean Square residual (SRMR), dan Root-Mean-Square Error of Approximation (RMSEA)

\section{MODEL PENGUKURAN}

Model pengukuran mengandungi tiga konstruk kajian; tanggapan politik dan konflik hubungan sebagai konstruk urutan pertama ( $1^{\text {st }}$ order $)$, manakala menyembunyikan pengetahun pula sebagai konstruk urutan kedua ( $2^{\text {nd }}$ order). Ujian Analisis Faktor Pengesahan yang dijalankan menunjukkan model yang dicadangkan oleh penyelidik menunjukkan nilai indeks padanan yang baik serta memenuhi kriteria yang dicadangkan oleh para sarjana (Hair et al., 2010): Chi-Square $(\chi 2)=$ $516.80, d f=183$ pada $p \leq 0.001 ; \mathrm{CFI}=0.95$; $\mathrm{TLI}=0.94$;
RMSEA $=0.07 ; \mathrm{SRMR}=0.05$. Nilai pekali terpiawai bagi semua indikator, secara statistiknya, adalah signifikan dan mempunyai nilai antara 0.79 hingga 0.94 ; dan ini membuktikan setiap instrumen pengukuran mempunyai kesahan konvergen yang baik.

Seterusnya perbandingan model alternatif menerusi ujian perbezaan Chi-square dijalankan untuk memastikan kesahan diskriminan bagi instrumen pengukuran. Seperti yang ditunjukkan dalam Jadual 1, perbezaan atau pembaikan pada nilai Chi-square yang signifikan dengan nilai $p \leq 0.001$, dan indeks fit yang semakin baik bagi Model 3-faktor apabila dibandingkan dengan setiap model alternatif lain membuktikan bahawa semua konstruk kajian mempunyai kesahan diskriminan yang baik.

Seterusnya, ujian statistik deskriptif, ujian kebolehpercayaan dan korelasi dijalankan bagi menerangkan data dan hubungan bivariat antara pemboleh ubah. Jadual 2 menunjukkan keputusan nilai min, sisihan piawai, korelasi dan kebolehpercayaan untuk pemboleh ubah bersandar dan pemboleh ubah tidak bersandar. Keputusan analisa ini menunjukkan hubungan korelasi yang signifikan antara pemboleh ubah dengan nilai $p$ $\leq 0.01$. Tanggapan politik mempunyai hubungan yang signifikan dengan konflik hubungan ( $r=0.51, p \leq 0.01$ ), dan dengan tingkah laku menyembunyikan pengetahuan ( $r=0.58, p \leq 0.01)$. Konflik hubungan juga mempunyai hubungan yang signifikan dengan menyembunyikan pengetahuan $(r=0.41, p \leq 0.01)$. Jadual 2 juga mempamerkan keputusan kebolehpercayaan Cronbach's Alpha yang baik bagi setiap konstruk dengan nilai antara .90 hingga .95 .

\section{MODEL BERSTRUKTUR}

Kesahan dan kebolehpercayaan model pengukuran yang baik membolehkan pengujian hipotesis dijalankan dalam langkah yang seterusnya. Hubungan langsung dan tidak langsung menerusi pemboleh ubah pengantara diuji menggunakan kaedah bootstrapping dengan 10,000 persampelan semula. Indeks padanan bagi model berstruktur menunjukkan padanan model yang baik: Chisquare $(\chi 2)=516.80 ; d f=183$ dengan nilai $p \leq 0.001$; $\mathrm{CFI}=.95, \mathrm{TLI}=.94, \mathrm{RMSEA}=0.07, \mathrm{SRMR}=0.05$. Rajah 1 menunjukkan nilai pekali terpiawai (standardised coefficient) bagi setiap hubungan antara pemboleh ubah-pemboleh ubah dalam model kajian. Hasil ujian mendapati hubungan yang signifikan antara tanggapan politik dengan tingkah laku menyembunyikan pengetahuan $(\beta=0.53, p \leq 0.001)$; tanggapan politik dengan konflik hubungan $(\beta=0.54, p \leq 0.001)$; dan konflik hubungan dengan tingkah laku menyembunyikan pengetahuan $(\beta=0.20, p \leq 0.01)$.

Akhir sekali, bagi kesan tidak langsung, dapatan kajian menunjukkan kesan yang signifikan antara tanggapan politik dengan tingkah laku menyembunyikan pengetahuan menerusi konflik hubungan sebagai pengantara $(\beta=0.03, p \leq 0.05)$. Hubungan yang 
JADUAL 1. Ujian perbezaan Chi-Square bagi model pengukuran

\begin{tabular}{|c|c|c|c|c|c|c|c|c|}
\hline Model & $x^{2}$ & $d f$ & $\Delta \chi^{2}$ & $\Delta d f$ & RMSEA & SRMR & TLI & CFI \\
\hline $\begin{array}{l}\text { Model 3-faktor } \\
\text { (Model kajian) }\end{array}$ & 516.80 & 183 & - & - & .07 & .05 & .94 & .95 \\
\hline $\begin{array}{l}\text { Model 2-faktor } \\
\text { (gabungan pemboleh ubah tidak bersandar } \\
\text { dan pengantara menjadi satu konstruk) }\end{array}$ & 556.55 & 184 & $39.75^{*}$ & 1 & .08 & .06 & .90 & .93 \\
\hline $\begin{array}{l}\text { Model 1-faktor } \\
\text { (gabungan semua pemboleh ubah menjadi } \\
\text { satu konstruk) }\end{array}$ & 575.58 & 186 & $58.77^{*}$ & 3 & .08 & .6 & .90 & .91 \\
\hline
\end{tabular}

Nota: $\mathrm{N}=339 * p \leq 0.01$

JADUAL 2. Min skor, sisihan piawai, korelasi dan kebolehpercayaan

\begin{tabular}{lccccc}
\hline Konstruk & Min & Sisihan piawai & 1 & 2 & 3 \\
\hline 1. Tanggapan politik & 2.22 & 0.87 & $(0.90)$ & & \\
2. Konflik hubungan & 2.11 & 1.00 & $.51^{*}$ & $(0.95)$ & \\
3. Menyembunyikan pengetahuan & 1.87 & 0.74 & $.58^{*}$ & $.41^{*}$ & $(0.93)$ \\
\hline
\end{tabular}

Nota: $* \mathrm{p} \leq .01$

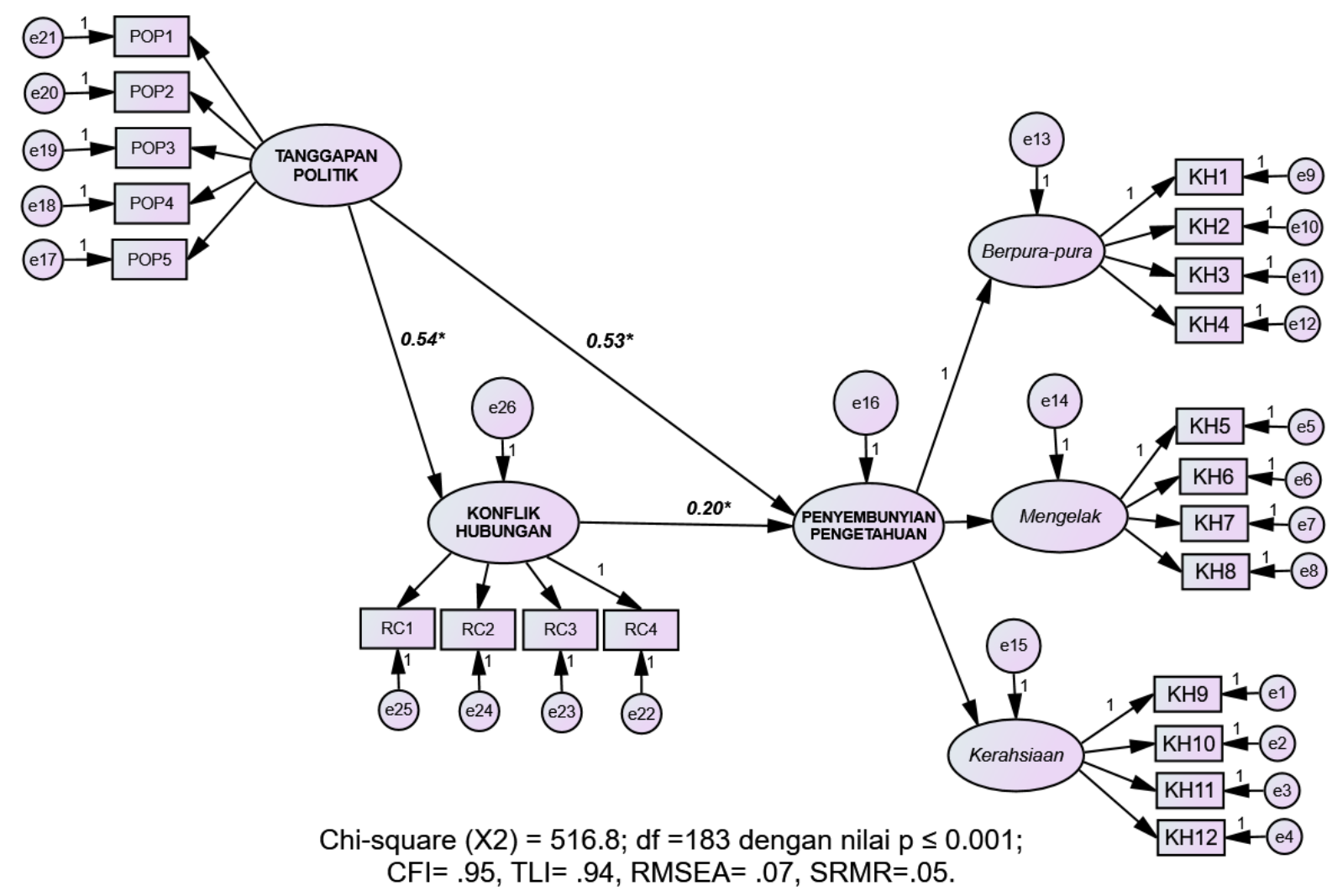

RAJAH 1. Model berstruktur, indeks padanan dan nilai pekali terpiawai bagi setiap hubungan antara pemboleh ubah kajian Nota: $* \mathrm{p} \leq 0.01$ 
signifikan ini adalah hasil ujian bootstrapping biascorrected 95\% menunjukkan sela keyakinan hubungan tidak langsung antara tanggapan politik dan tingkah laku menyembunyikan pengetahuan menerusi konflik hubungan bagi kedua-dua had LLCI dan ULCI yang tidak mengandungi nilai sifar $(0.02 ; 0.19)$. Secara keseluruhan model kajian menerangkan sebanyak 44 peratus varian dalam tingkah laku menyembunyikan pengetahuan.

\section{PERBINCANGAN}

Objektif kajian ini adalah untuk menyiasat hubungan antara tanggapan politik dalam pasukan dan tingkah laku menyembunyikan pengetahuan dalam kalangan pekerja yang bekerja secara berpasukan, dan peranan konflik hubungan sebagai pengantara dalam hubungan antara dua konstruk tersebut. Hasil analisis kajian menunjukkan hubungan yang signifikan bagi: i) kesan langsung tanggapan politik terhadap tingkah laku menyembunyikan pengetahuan, dan ii) kesan tidak langsung tanggapan politik terhadap menyembunyikan pengetahuan menerusi pemboleh ubah pengantara konflik hubungan.

Pertama, hubungan langsung yang signifikan antara tanggapan politik dan menyembunyikan pengetahuan adalah konsisten dengan teori pemuliharaan sumber (Hobfoll 1989) yang mengatakan bahawa pekerja akan sedaya upaya melindungi sumber yang mereka ada apabila mereka melihat wujudnya ancaman terhadap sumber tersebut. Dalam kajian ini misalnya, tahap politik yang tinggi dalam kalangan rakan sepasukan dilihat sebagai satu ancaman di tempat kerja. Justeru, sebagai strategi menangani ancaman kehilangan sumber, pekerja akan menyembunyikan pengetahuan yang dimiliki apabila diminta oleh rakan sekerja. Dalam hal ini pengetahuan yang dimiliki oleh seseorang pekerja dianggap sebagai satu sumber yang bernilai dalam memastikan kebolehsaingan beliau di tempat kerja. Setiap penyelidik biasanya memiliki pengetahuan atau kepakaran dalam bidang yang tertentu sama ada dari segi teori mahupun metodologi penyelidikan yang dijalankan. Kepakaran dan pengetahuan yang dimiliki ini dilihat sebagai kuasa yang boleh digunakan bagi mengukuhkan kedudukan ahli dalam sesuatu projek penyelidikan yang disertainya. Hubungan yang signifikan antara tanggapan politik dan menyembunyikan maklumat juga selaras dengan teori pertukaran sosial (Blau 1964) dan norma timbal balas (Gouldner 1960) yang mencadangkan bahawa pekerja yang bekerja dalam pasukan berkongsi sumber seperti pengetahuan, kepakaran dan persahabatan sebagai cara untuk mencapai matlamat yang dikongsi bersama; sebagai balasan beliau juga mengharapkan pertukaran yang sama daripada ahli-ahli dalam pasukan. Penglibatan politik yang tinggi dalam kalangan ahli pasukan akan menghasilkan ketidakpastian dan kekaburan dalam persekitaran pekerjaan yang seterusnya mempengaruhi pertukaran di antara kedua-dua pihak (cth: pertukaran yang tidak seimbang). Sebagai contoh, ahli-ahli penyelidik diharapkan untuk saling berkongsi maklumat dan kepakaran. Walau bagaimanapun, penglibatan mereka dalam politik untuk mencapai kepentingan peribadi dilihat sebagai mewujudkan ketidakseimbangan dalam pertukaran sosial. Justeru, pekerja yang terkesan atau mengalami layanan buruk dari rakan sekerja yang terlibat dengan kelakuan politik akan membalas secara negatif dengan bertindak menyembunyikan pengetahuan apabila diminta oleh rakan sekerja. Secara empirikal, dapatan kajian ini selari dengan dapatan kajian lepas yang mengkaji hubungan antara dua konstruk tersebut (cth. Malik et al. 2019; Baloch et al. 2017; Cohen \& Diamant 2017).

Kedua, dapatan signifikan kajian mengenai hubungan tidak langsung antara tanggapan politik dan tingkah laku menyembunyikan pengetahuan menerusi pemboleh ubah konflik hubungan adalah konsisten dengan dapatan kajian lepas. Secara teorinya, hubungan tidak langsung tersebut dapat dijelaskan dengan menggunakan teori pemuliharaan sumber (Hobfoll 1989) yang mengatakan bahawa pekerja akan sentiasa terdedah kepada ancaman kehilangan atau pertambahan sumber. Misalnya, dalam kajian ini, tahap penglibatan dalam politik yang tinggi dilihat sebagai ancaman kepada sumber sedia ada (cth: hubungan dan persekitaran kerja yang harmoni dan kondusif) yang berupaya mencetuskan ketegangan emosi serta kekecewaan dalam diri pekerja. Sebagai usaha untuk mengekalkan dan melindungi sumber yang ada daripada ancaman masa kini dan masa hadapan, pekerja akan cuba mengelak daripada berhubungan atau berkomunikasi dengan rakan sekerja yang terlibat dengan tingkah laku politik. Usaha melindungi sumber ini terzahir dalam bentuk konflik hubungan dalam kalangan pekerja. Konflik hubungan ini seterusnya akan menyebabkan pekerja bertindak menyembunyikan pengetahuan apabila diminta oleh rakan sekerja sebagai usaha mengekalkan atau melindungi sumber (pengetahuan) yang dimiliki. Dalam kontek pasukan penyelidik pula, pengetahuan sememangnya dianggap sebagai sumber yang penting, dan hubungan yang baik antara ahli adalah diperlukan untuk menghasilkan penyelidikan yang berkualiti. Namun, penglibatan ahli pasukan dalam politik demi mencapai kepentingan kendiri akan menjejaskan hubungan baik sesama ahli, dan ini seterusnya akan menyebabkan ahli tidak teragakagak untuk menyembunyikan pengetahuan sebagai cara terakhir untuk mempertahankan sumber yang dimiliki (cth., pengetahuan). Dapatan kajian ini selari dengan dapatan emipirikal oleh pengkaji terdahulu yang mendapati peranan konflik hubungan sebagai perantara yang signifikan dalam hubungan antara tanggapan politik dengan prestasi seperti menjejaskan prestasi, tingkah laku kewargaan organisasi dan kreativiti di kalangan pekerja (Bai et al. 2015).

Secara teorinya kajian ini menyumbang kepada literatur pengurusan pengetahuan dengan mengkaji anteseden yang meramal tingkah laku menyembunyikan 
pengetahuan dalam kalangan pekerja yang bekerja dalam pasukan. Tanggapan politik didapati bukan hanya meramal tingkah laku menyembunyikan pengetahuan secara langsung tetapi juga secara tidak langsung menerusi konflik hubungan sebagai pengantara.

Kajian in juga secara praktikal menyumbang kepada pihak pengurusan organisasi terutamanya dari polisi dan pengurusansumbermanusia.Dapatankajianmenunjukkan semakin tinggi tanggapan politik di tempat kerja maka semakin tinggi kecenderungan seseorang pekerja untuk menyembunyikan pengetahuan apabila diminta oleh rakan sekerja. Justeru, untuk mengurangkan tingkah laku tersebut, pihak pengurusan harus menguruskan politik di tempat kerja dengan cara yang berkesan. Dari segi polisi misalnya, peraturan dan prosedur hendaklah jelas dan telus agar tiada sesiapa dapat memanipulasi sumbersumber organisasi untuk kepentingan peribadi. Sebagai contoh, pihak pengurusan yang bertanggungjawab menguruskan hal ehwal penyelidikan di setiap universiti boleh memperkenalkan polisi penggunaan dana-dana penyelidikan bagi memastikan kurangnya manipulasi kepada geran. Manakala, ketua pasukan penyelidikan pula perlu memastikan agihan sumber-sumber yang adil dan telus dalam kalangan ahli bagi mengurangkan risiko aktiviti berpolitik berlaku dalam pasukan.

Selain itu, komunikasi antara pengurus, ketua jabatan atau pasukan dan pekerja hendaklah berlaku dalam keadaan yang harmoni dan jelas. Ini untuk memastikan ketidakpastian dan kekaburan yang berpunca daripada penglibatan pekerja dalam politik boleh dikurangkan. Pekerja harus diingatkan mengenai keutamaan yang perlu diberikan kepada matlamat bersama, dan bukan kepentingan kendiri semata-mata kerana tindakan ini akan memberi kesan kepada pencapaian pasukan atau organisasi secara keseluruhan.

\section{BATASAN DAN CADANGAN}

Terdapat beberapa batasan yang perlu diambil kira dalam memahami dapatan kajian ini. Kajian ini dijalankan menggunakan persampelan bukan berkebarangkalian, maka generalisasi hasil kajian adalah terhad dan digunakan untuk mewakili populasi penyelidik di Malaysia. Bagi meminimakan batasan ini, kajian masa hadapan dicadangkan untuk dilakukan terhadap sampel pekerja yang berbeza. Selain itu, kajian ini dijalankan secara keratan rentas; dapatan kajian ini tidak mungkin dapat memberi gambaran yang menyeluruh mengenai hubungan sebab dan kesan bagi konstruk yang dikaji. Justeru, kajian masa hadapan perlu dilakukan secara longitudinal supaya mendapat pemahaman yang lebih tepat mengenai hubungan yang dikaji. Kajian ini juga bergantung sepenuhnya terhadap kaji selidik kuantitatif. Untuk memahami tingkah laku menyembunyikan pengetahuan dalam kalangan pekerja secara lebih mendalam, penyelidik disarankan untuk menjalankan kajian kualitatif.
Akhir sekali, berdasarkan kepada dapatan kajian ini mengenai kepentingan tanggapan politik dan konflik hubungan dalam meramal tingkah laku menyembunyikan pengetahuan, kajian masa depan dicadangkan untuk menyiasat peranan faktor situasi lain seperti gaya kepimpinan dan iklim organisasi dalam mempengaruhi tingkah laku tersebut.

\section{RUJUKAN}

Abrams, L. C., Cross, R., Lesser, E. \& Levin, D. Z. 2003. Nurturing interpersonal trust in knowledge-sharing networks. Academy of Management Perspectives 17(4): 64-77.

Anderson, J.C. \& Gerbing, D.W. 1988. Structural equation modeling in practice: A review and recommended twostep approach. Psychological Bulletin 103(3): 411-423.

Arendt, J. F., Kugler, K. G. \& Brodbeck, F. C. 2021. Conflicting relational models as a predictor of (in) justice perceptions and (un) cooperative behavior at work. Journal of Theoretical Social Psychology 5(3): 183-202.

Arshad, R. \& Ismail, I. R. I. 2018. Workplace incivility and knowledge hiding behavior: Does personality matter? Journal of Organizational Effectiveness 5(3): 278-288.

Bai, Y., Han, G. H. \& Harms, P. D. 2015. Team conflict mediates the effects of organizational politics on employee performance: A cross-level analysis in China. Journal of Business Ethics 139(1): 95-109.

Bakker, A. B. \& Demerouti, E. 2007. The job demandsresources model: State of the art. Journal of Managerial Psychology 22(3): 309-328.

Baloch, M. A., Meng, F., Xu, Z., Cepeda-Carrion, I., Danish \& Bari, M. W. 2017. Dark Triad, perceptions of organizational politics and counterproductive work behaviors: The moderating effect of political skills. Frontiers in Psychology 8: 1-14.

Bartol, K. M. \& Srivastava, A. 2002. Encouraging knowledge sharing: The role of organizational reward systems. Journal of Leadership \& Organizational Studies Organizational Studies 9(1): 64-76.

Blau, P. M. 1964. Exchange and Power in Social Life. New York, NY: John Wiley \& Sons, Inc.

Bogilović, S., Černe, M. \& Škerlavaj, M. 2017. Hiding behind a mask? Cultural intelligence, knowledge hiding, and individual and team creativity. European Journal of Work and Organizational Psychology 26(5): 710-723.

Burmeister, A., Fasbender, U. \& Gerpott, F. H. 2019. Consequences of knowledge hiding: The differential compensatory effects of guilt and shame. Journal of occupational and organizational psychology 92(2): 281304.

Cabrera, A. \& Cabrera, E. F. 2002. Knowledge-sharing dilemmas. Organization Studies 23(5): 687-710.

Cerne, M., Babic, K., Connelly, C. E. \& Skerlavaj, M. 2015. Team-level knowledge hiding, social leader-member exchange, and prosocial motivation. Academy of Management Proceedings 2017(1): 13802

Černe, M., Hernaus, T., Dysvik, A. \& Škerlavaj, M. 2017. The role of multilevel synergistic interplay among team mastery climate, knowledge hiding, and job characteristics in stimulating innovative work behavior. Human Resource Management Journal 27(2): 281-299. 
Cohen, A. \& Diamant, A. 2017. The role of justice perceptions in determining counterproductive work behaviors. International Journal of Human Resource Management 30(20): 2901-2924.

Connelly, C. E., Zweig, D., Webster, J. \& Trougakos, J. P. 2012. Knowledge hiding in organizations. Journal of Organizational Behavior 33(1): 64-88.

De Dreu, C. K. W. \& Weingart, L. R. 2003. Task versus relationship conflict, team performance, and team member satisfaction: A meta-analysis. Journal of Applied Psychology 88(4): 741-749.

de Wit, F. R. C., Greer, L. L. \& Jehn, K. A. 2012. The paradox of intragroup conflict: A meta-analysis. The Journal of Applied Psychology 97(2): 360-90.

Filstad, C., Simeonova, B. \& Visser, M. 2018. Crossing power and knowledge boundaries in learning and knowledge sharing. The Learning Organization 25(3): 159-168.

Fong, P. S. W., Men, C., Luo, J. \& Jia, R. 2018. Knowledge hiding and team creativity: the contingent role of task interdependence. Management Decision 56(2): 329-343.

Gouldner A. W. 1960. The norm of reciprocity: A preliminary statement. American Sociological Review 25(2): 161-78.

Han, M. S., Masood, K., Cudjoe, D. \& Wang, Y. 2020. Knowledge hiding as the dark side of competitive psychological climate. Leadership \& Organization Development Journal 42(2): 195-207.

Hobfoll, S. E. 1989. Conservation of resources: A new attempt at conceptualizing stress. American Psychologist 44(3): 513-524.

Hochwarter, W. A., Kacmar, C., Perrewe, P. L. \& Johnson, D. 2003. Perceived organizational support as a mediator of the relationship between politics perceptions and work outcomes. Journal of Vocational Behavior 63(3): 438456.

Hochwarter, W. A., Rosen, C. C., Jordan, S. L., Ferris, G. R., Ejaz, A. \& Maher, L. P. 2020. Perceptions of organizational politics research: past, present, and future. Journal of Management 46(6), 879-907.

Jehn, K. A. 1995. A multimethod examination of the benefits and detriments of intragroup conflict. Administrative Science Quarterly 40(2): 256-282.

Jehn, K. A. 1997. A qualitative analysis of conflict types and dimensions in organizational groups. Administrative Science Quarterly 42(3): 530-557.

Jung, E. J., \& Lee, S. 2015. The combined effects of relationship conflict and the relational self on creativity. Organizational Behavior and Human Decision Processes 130: 44-57.

Kwahk, K. Y. \& Park, D. H. 2016. The effects of network sharing on knowledge-sharing activities and job performance in enterprise social media environments. Computers in Human Behavior 55: 826-839.

Malik, O. F., Shahzad, A., Raziq, M. M., Khan, M. M., Yusaf, S. \& Khan, A. 2019. Perceptions of organizational politics, knowledge hiding, and employee creativity: The moderating role of professional commitment. Personality and Individual Differences 142: 232-237.

Manata, B. 2016. Exploring the association between relationship conflict and group performance. Group Dynamics: Theory, Research, and Practice 20(2): 93.

Meisler, G., Drory, A. \& Vigoda-Gadot, E. 2019. Perceived organizational politics and counterproductive work behavior: The mediating role of hostility. Personnel Review 49(8): 1505-1517.

Men, C., Fong, P. S., Huo, W., Zhong, J., Jia, R. \& Luo, J. 2018. Ethical leadership and knowledge hiding: a moderated mediation model of psychological safety and mastery climate. Journal of Business Ethics 166: 461-471.

Mitratech Holdings Inc. 2016. Catching The Wave: Legal Technology Spend at \$3 Billion and Growing. Available at http://www.mitratech.com/resource-hub/white-papers/ catching_the_wave_wp/

Mohammed, S. \& Angell, L. C. 2004. Surface- and deep-level diversity in workgroups: Examining the moderating effects of team orientation and team process on relationship conflict. Journal of Organizational Behavior 25(8): 10151039.

Panopto 2018. The Workplace Knowledge and Productivity Report. Available at https://www.panopto.com/ resource/ valuing-workplace-knowledge/\#Report

Rhee, Y. W. \& Choi, J. N. 2017. Knowledge management behavior and individual creativity: Goal orientations as antecedents and in-group social status as moderating contingency. Journal of Organizational Behavior 38(6): 813-832.

Rosen, C. C., Kacmar, K. M., Harris, K. J., Gavin, M. B. \& Hochwarter, W. A. 2016. Workplace Politics and Performance Appraisal: A two-study, multilevel field investigation. Journal of Leadership and Organizational Studies 24(1): 20-38.

Semerci, A. B. 2018. Examination of knowledge hiding with conflict, competition and personal values. International Journal of Conflict Management 30(1): 111-131. d

Serenko, A. \& Bontis, N. 2016. Understanding counterproductive knowledge behavior: Antecedents and consequences of intra-organizational knowledge hiding. Journal of Knowledge Management 20(6): 1199-1224.

Sinar Harian. 2020. KPM peruntuk RM250 juta untuk empat geran penyelidikan. Available at https://www.sinarharian. com.my/article/69830/BERITA/Nasional/KPM-peruntukRM250-juta-untuk-empat-geran-penyelidikan.

Sulea, C., Virga, D., Maricutoiu, L. P., Schaufeli, W., Dumitru, C. Z. \& Sava, F. A. 2012. Work engagement as mediator between job characteristics and positive and negative extra-role behaviors. Career Development International 17(3): 188-207.

van Knippenberg, D., Nishii, L. H. \& Dwertmann, D. J. 2020. Synergy from diversity: Managing team diversity to enhance performance. Behavioral Science \& Policy 6(1): 75-92.

Wall, J. A. \& Callister, R. R. 1995. Conflict and its management. Journal of Management 21(3): 515-558.

Wang, S. \& Noe, R. A. 2010. Knowledge sharing: A review and directions for future research. Human Resource Management Review 20(2): 115-131.

Wiltshire, J., Bourdage, J. S. \& Lee, K. 2013. Honesty-humility and perceptions of organizational politics in predicting workplace outcomes. Journal of Business and Psychology 29(2): 235-251.

Witt, L. A., Hilton, T. F. \& Hochwarter, W. A. 2001. Addressing politics in matrix teams. Group \& Organization Management 26(2): 230-247.

$\mathrm{Yu}$, L. \& Zellmer-Bruhn, M. 2017. Introducing team mindfulness and considering its safeguard role against conflict transformation and social undermining. Academy of Management Journal 61(1): 324:347.

$\mathrm{Yu}, \mathrm{L}$. \& Zellmer-Bruhn, M. 2017. Introducing team mindfulness and considering its safeguard role against conflict transformation and social undermining. Academy of Management Journal 61(1): 324:347. 
Yun, Y.-J. \& Lee, K.-J. 2017. Social skills as a moderator between R \& D personnel's knowledge sharing and job performance performance. Journal of Managerial Psychology 32(5): 387-400.

Zettler, I. \& Hilbig, B. E. 2010. Honesty-humility and a person-situation interaction at work. European Journal of Personality 24(7): 569-582.

Zhang, Z. \& Min, M. 2019. The negative consequences of knowledge hiding in NPD project teams: The roles of project work attributes. International Journal of Project Management 37(2): 225-238.

Zhao, H., Liu, W., Li, J. \& Yu, X. 2019. Leader-member exchange, organizational identification, and knowledge hiding: The moderating role of relative leader-member exchange. Journal of Organizational Behavior 40(7): 834-848

Zhao, H. \& Xia, Q. 2019. Nurses' negative affective states, moral disengagement, and knowledge hiding: the moderating role of ethical leadership. Journal of Nursing Management: 27(2): 357-370.
Norulhuda Tajuddin

UKM-Graduate School of Business

Universiti Kebangsaan Malaysia

43600 UKM Bangi, Selangor, MALAYSIA.

Fakulti Pengurusan Perniagaan

Universiti Teknologi MARA Cawangan Pahang

Kampus Raub

27600 Raub, Pahang, MALAYSIA.

E-Mel: alhudatajuddin583@uitm.edu.my

Rasidah Arshad (penulis koresponden)

Fakulti Ekonomi dan Pengurusan

Universiti Kebangsaan Malaysia

43600 UKM Bangi, Selangor, MALAYSIA

E-Mel: rasida@ukm.edu.my 